\title{
СТАН СФОРМОВАНОСТІ ВАЛЕОЛОГІЧНОЇ КОМПЕТЕНТНОСТІ СТУДЕНТІВ-МЕДИКІВ ЗАКЛАДІВ ВИЩОЇ ОСВІТИ
}

\author{
OKSANA BOYCHUK-TOVSTA, Candidate of Medical Sciences, \\ Assistant Professor, Department of Dentistry, Ivano-Frankivsk \\ National Medical University, Postgraduate Education Institute

\section{THE STATE OF FORMATION OF THE VALEOLOGICAL COMPETENCE OF MEDICAL STUDENTS OF INSTITUTIONS OF HIGHER EDUCATION}

У статті теоретично обгрунтовано суть поняття "валеологічна компетентність". Виявлено, що майбутні медики дуже добре обізнані із шляхами саморегуляції власного здоров'я та утвердження здорового способу життя, чітко усвідомлюють необхідність фізичного самовдосконалення та ведення здорового способу життя; розуміють потребу дотримуватись режиму роботи й відпочинку та їх вплив на працездатність людини. Доведено, що майбутні лікарі ознайомлені з основними факторами впливу навколишнього середовища на здоров'я людини. Однак, з-поміж майбутніх фахівців виявлено таких, котрі частково обізнані з проектуванням сукупності заходів з утвердження здорового способу життя в сім'ї та різних соціальних закладах, і їм не вистачає знань щодо прогнозування стану індивідуального та суспільного здоров'я.

Ми впевнились, що домінуючими для майбутніх лікарів $є$ змістовне життя, повноцінне харчування, заняття спортом та саморозвиток і самовдосконалення. Пріоритетними для більшої частини опитаних залишаються здоров'я, сім'я, кар'єра, кохання і освіта. Надзвичайно важливим молодь вважає збереження здоров'я і чітко усвідомлює, що цьому, беззаперечно, сприятиме її спосіб життя. Майбутні лікарі проявили зацікавленість до формування вмінь щодо використання прийомів контролю за власним здоров'ям та методики прогнозування здоров'я, тривалості жит-

(c) О. Бойчук-Товста тя, що сприятиме підвищенню рівня здоров'я, корекції власного способу життя та життєвих цінностей майбутніх пацієнтів. Респонденти вважають, що для пропаганди валеологічної освіти доцільно використовувати лекції, тренінги, індивідуальні бесіди 3 пацієнтами, що стануть ефективним засобом для формування валеологічної обізнаності, а також науковопрактичні конференції та круглі столи.

Ключові слова: валеологічна компетентність, майбутні лікарі, культура здоров'я, здоровий спосіб життя.

Summary. The essence of the concept of "valeological competence" is theoretically substantiated in the article. It has been found that future physicians are well aware of the ways of self-regulation of their own health and the promotion of a healthy lifestyle, clearly aware of the need for physical self-improvement and a healthy lifestyle; very well understand the need to adhere to the regime of work and rest and their impact on human performance. Future well-known physicians are very aware of the major factors of environmental impact on human health. However, future professionals have identified those who are partially aware of the design of a set of measures to promote healthy lifestyles in the family and in various social institutions and lack knowledge in predicting individual and public health.

Dominant for future physicians are meaningful life, good nutrition, sports and self-development and selfimprovement. Health, family, career, love, and education are the priorities for most respondents. It is extremely important for young people to consider the preservation of health and to make it clear that their lifestyle will undoubtedly contribute to this. Future physicians have shown an interest in developing skills in the use of selfcontrol techniques and health forecasting techniques, longevity that will enhance health, correct their own lifestyles and the life values of future patients. Respondents believe that it is advisable to use lectures, trainings, individual interviews with patients to promote valeological education, which will become an effective tool for the formation of valeological awareness, as well as scientific and practical conferences and round tables.

Key words: valeological competence, future doctors, health culture, healthy lifestyle

Мета: виявити стан теоретичної і практичної валеологічної компетентності студентів медичних закладів вищої освіти.

Постановка проблеми в загальному вигляді. Сучасні трансформаційні процеси, які відбуваються в українському соціумі, негативні тенденції щодо зростання захворюваності учнівської та студентської молоді, масове поширення шкідливих звичок у молодіжному середовищі зумовлюють реформування системи охорони здоров'я в Україні. Молодь під тиском психоемоційного напруження байдуже ставиться до власного здоров'я, що знецінює не тільки іiї індивідуальне здоров'я, а й суспільне здоров'я нації в цілому (Козуб та Чаленко, 2016, с. 8). Занепокоєння викликає й те, що дослідники вказують 
на несформованість у студентів медичних освітніх закладів мотивації на тривале здорове життя та низький рівень валеологічних знань (Бондаренко, 2008, с. 9), відсутність переконань щодо необхідності дотримання здорового способу життя (Власов, 2012). Змінити ставлення студента до власного здоров'я, раціонального способу життя можливо за умови розуміння ним означених цінностей, надання пріоритетності збереження фізичного та психічного здоров'я через освіту. Відтак проблема збереження та відповідального ставлення до здоров'я майбутніх лікарів, формування їх валеологічної компетентності є актуальною.

Аналіз досліджень і публікацій. Аналіз та узагальнення даних наукових праць зумовили виділення декількох напрямів досліджуваної проблеми, як-от: особливості свідомого та ціннісного ставлення до здоров'я розкриваються у роботах М. Авдєєва, С.Алексєєнко, О. Васюк, Н. Денисенко, Г. Нікіфорова, О. Сапожник, В.Смірнова (Алексеенко, Авдеева \& Дробот, 2013; Radziminska, WeberRajek, Lulinska-Kuklik, Kazmierczak \& Moska, 2016; Сапожник, 2010); окремим аспектам формування культури здоров'я студентів медичних закладів присвячені дослідження С. Козуб, В. Назарук, Л. Новакової, І. Шостак (Козуб \& Чаленко, 2016; Haзарук, 2014; Шостак, 2017). Питання валеологічної підготовки студентів висвітлена у працях Б. Максимчука, Н. Сєдової.

У контексті піднятої проблеми важливими є результати вислідів В. Азаренко, В. Бобрицької, О. Бондаренко, В. Слізарова, В. Нестеренко, Я. Остафійчука, Г. Презлятої, Н. Самойлової, В. Сидоренко (Бондаренко, 2008; Слізаров, 2016; Остафійчук, 2014), котрі акцентують увагу на питанні щодо визначення суті та розвитку валеологічної компетентності студентів.

Однак, аналіз наукових джерел показав, що проблема формування валеологічної компетентності студентів медичних закладів вищої освіти вивчена недостатньо.

Виклад основного матеріалу дослідження. Вивченняення стану валеологічної обізнаності студентів медичних закладів вищої освіти було б не можливим без обгрунтування суті дефініції "валеологічна компетентність" майбутнього фахівця.

Аналіз напрацювань науковців 3 означеної проблеми виявив достойну увагу інтерпретації поняття "валеологічна компетентність", яка розглядається дослідниками як інтегративне утворення особистості, що $є$ складовою життєвої компетентності (знання, цінності і мотиви, валеологічна позиція, діяльність щодо оздоровлення себе і своїх вихованців) (Бондаренко, 2008); наявність у майбутнього фахівця сукупності необхідних знань, умінь та навичок з формування, збереження і зміцнення здоров'я своїх вихованців та власного здоров'я у нерозривній єдності духовного, соціального, психічного та фізичного аспектів, а також прагнення здоров'єтворчості, розуміння значущості і потреби постійного духовного розвитку на основі самовдосконалення в особистісному та професійному аспектах (Єлізаров, 2016).

У контексті нашого дослідження імпонує визначення валеологічної компетентності студентів-медиків, запропоноване Я. Остафійчуком (Остафійчук, 2014), який розглядає означену дефініцію як результат навчального процесу, складну інтегративну рису особистості, що проявляється у здатності зберігати та реалізувати власну здоров'язбережну позицію, адекватно оцінювати власний стан здоров'я, відповідно організовувати, добирати здоров'язбережні засоби з урахуванням можливостей організму, стану здоров'я, уносити корективи у спосіб життя.

Стан валеологічної обізнаності майбутніх лікарів діагностувався через самооцінку і здійснювався шляхом опитування (авторська анкета Я. Остафійчука "Моя валеологічна компетентність") (Остафійчук, 2014) та інтерпретації отриманих даних. Студенти, котрі взяли участь в експерименті, проявляли свою валеологічну компетентність, відповідаючи на запропоновані запитання опитувальника, що сформований з двох частин - теоретичної і практичної. Теоретична поінформованість студентів-медиків закладів вищої освіти розкривалася через знання респондентами таких тем, як розуміння суті "валеології" як науки, валеологічні складові здорового способу життя, важливі для молодих людей життєві цінності, побажання щодо розширення теоретичних знань з окремих валеологічних проблем.

В експерименті взяли участь 42 студенти-інтерни Навчально-науко- вого інституту післядипломної освіти Івано-Франківського національного медичного університету.

Аналіз результатів теоретичної частини опитувальника щодо розуміння суті, мети та завдань науки "валеологія" виявив феномен 100\% точності розкриття визначення означеної дефініції учасниками експерименту, відтак 94,4\% респондентів достовірно окреслюють мету валеологічної освіти, 88,9\% майбутніх лікарів правильно називають основні завдання валеології.

Наступним завданням опитувальника було визначення студентами-медиками ЗВО самооцінки щодо їх валеологічної обізнаності за п'ятибальною шкалою: "дуже добре обізнаний" оцінювалося у п'ять балів, "добре обізнаний" - чотири бали, "частково обізнаний" - три бали i "мало обізнаний" та "необізнаний" - відповідно два і один бали.

Отож репрезентація отриманих відповідей вказує на те, що майбутні медики дуже добре обізнані із шляхами саморегуляції власного здоров'я та утвердження здорового способу життя. Відтак $80,6 \%$ студентів усвідомлюють необхідність фізичного самовдосконалення та ведення здорового способу життя, 78,5\% респондентів дуже добре розуміють потребу дотримуватись режиму роботи i відпочинку та їх вплив на працездатність людини. Дуже добре обізнані майбутні лікарі $(75,5 \%)$ з основними факторами впливу навколишнього середовища на здоров'я людини.

У респондентів виявлено добрий рівень знань із тем, котрі розкривають суть здорового способу життя та його історичну ретроспективу $(65,0 \%$ відповідей), сучасні засоби занять рекреаційними видами спорту $(85,8 \%)$, а також засоби зміцнення здоров'я $(60,0 \%)$.

Однак 3-поміж майбутніх фахівців $€$ такі, які частково обізнані з проектуванням сукупності заходів з утвердження здорового способу життя в сім'ї та в різних соціальних закладах (80,0\% опитаних); 75,5\% респондентів не вистачає знань щодо прогнозування стану індивідуального та суспільного здоров'я. Виявлено й таких, котрі слабо орієнтуються у темах, що стосуються оволодіння прийомами валеометрії та проведення наукових досліджень 3 валеологічної проблеми.

Немаловажним для вирішення 
поставлених завдань дослідження стало визначення найважливіших, на думку студентів-медиків, валеологічних складових власного ведення здорового способу життя. Відтак використовуючи метод ранжування, вони повинні були з-поміж 13 запропонованих обрати за певною ієрархією складники, що є для них пріоритетними.

Отож підсумовуючи отримані результати, виявлено, що домінуючими для майбутніх лікарів $\epsilon$ змістовне життя, повноцінне харчування, заняття спортом та саморозвиток і самовдосконалення, позаяк більшість респондентів винесли їх на перші позиції 3 невеликим розривом у відсотковому співвідношенні (рис. 1).

Таким чином, на першому місці більше половиною студентів (61,9\%) беззаперечно вказано на змістовне життя; на другому місці для них важлодих людей до здорового способу життя відносять заняття руховою активністю і спортом, а 47,6\% опитаних на четверте за важливістю місце ставлять такий складник, як позитивний підхід до самого себе.

Однак слід відзначити, що значна частина майбутніх медичних працівників $(42,8 \%)$ не нехтують дотриманням правил гігієни статевого життя, на які вони вказали, як на п'яте місце в рейтингу, а саморозвиток і самовдосконалення посіли в них шосту позицію (35,7\% опитаних).

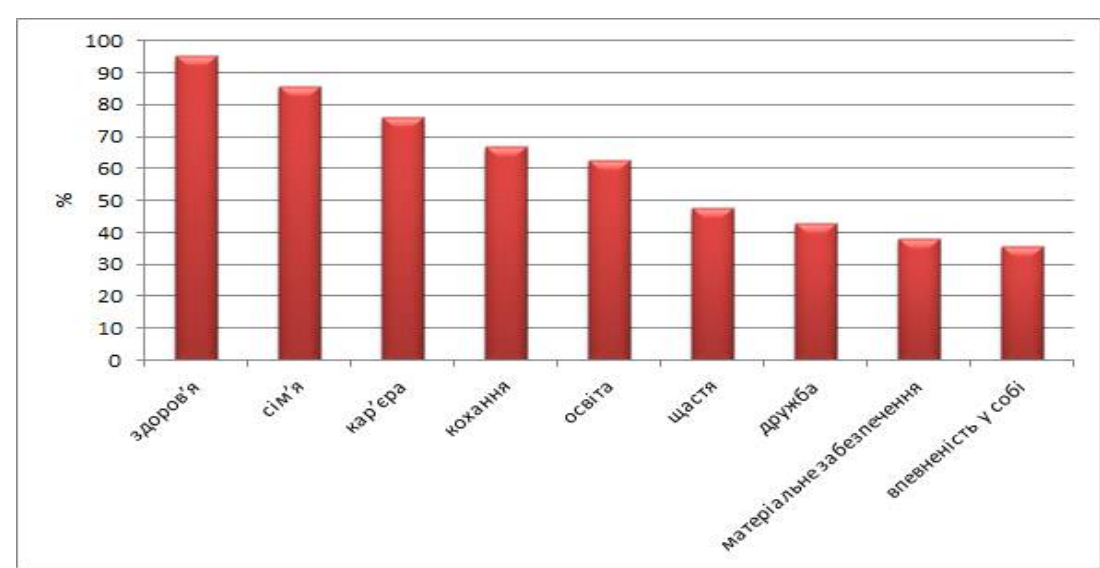

Рис. 2. Рангування власних життевих цінностей студентів-медиків ЗВО ливі повноцінне і раціональне харчування (57,1\% відповідей), 50,0\% мо-

$(76,2 \%)$, відтак - кохання $(66,7 \%)$ та освіта $(52,4 \%)$. Отримані відповіді інтерпретують те, що більшість студентів надзвичайно важливим вважають збереження здоров'я і чітко усвідомлюють, що цьому беззаперечно сприятиме їх спосіб життя. Однак життєво цінними для молодих людей $€$ і щастя, дружба, матеріальне забезпечення та впевненість у собі, яким вони відповідно відвели, шосте, сьоме, восьме та дев'яте місця в рейтингу.

Оскільки в ході дослідження було виявлено певні прогалини у валеологічній освіті студентів-медиків, то логічно було почути побажання респондентів, з яких валеологічних проблем вони хотіли б розширити власні теоретичні знання. Таким чином, найбільша кількість майбутніх

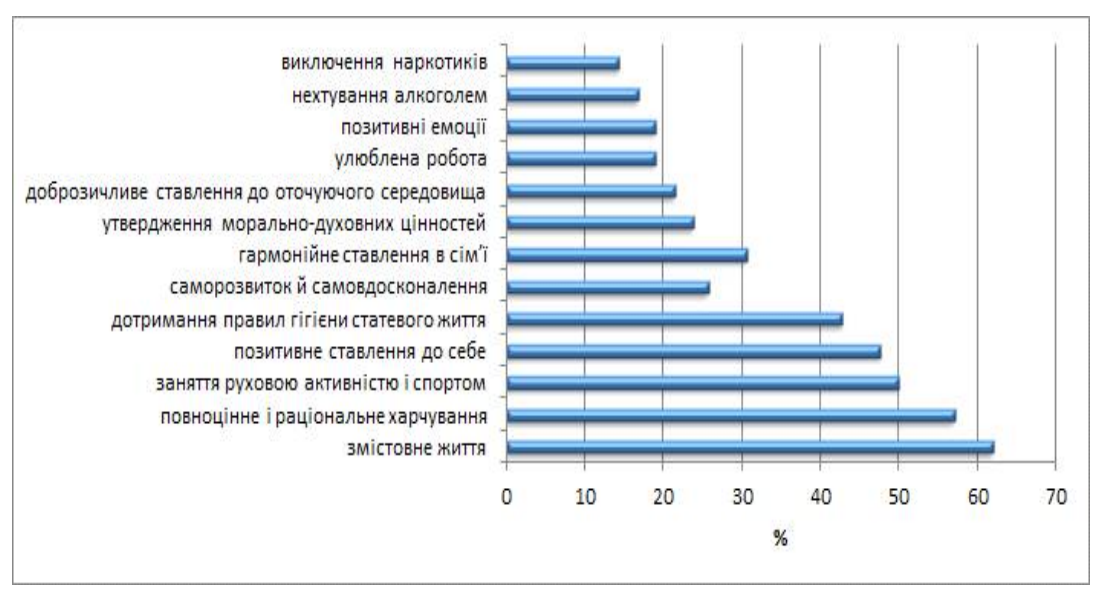

Рис. 1. Рейтинг ваюливих длямайбут ніх лікарів валеологічних складових здорового способужиття

Уваги заслуговує також і ієрархія власних життєвих цінностей майбутніх лікарів. Отже, на першому місці для левової частини опитаних $(95,2 \%)$ стоїть здоров'я, на другому сім'я $(85,7 \%)$, на третьому - кар'єра фахівців-медиків (85,8\%) прагнуть поповнити свої знання з валеологічних основ організації харчування; частина студентів $(76,2 \%)$ вказують на розширення обізнаності щодо нормативно-правового забезпечення валеології; на третє місці респонденти винесли валеологічні традиції українського народу $(64,3 \%)$; на четверте - духовні аспекти здоров'я $(52,4 \%)$. Менше половини опитаних $(47,6 \%)$ мало знають про психічне здоров'я, профілактику стресів та корекцію його наслідків.

Немаловажним для досягнення поставленої мети дослідження було виявлення практичної дієздатності майбутніх медиків. Відтак у практичній частині анкети студентам було поставлено п'ять запитань, що мали на меті визначити "3 яких практичних валеологічних компетенцій хотіли б сформувати вміння щодо володіння прийомами регулятивно-оздоровчої дії?" Отримані відповіді розподілилися наступним чином: $85,8 \%$ респондентів цікавлять фізичні вправи для зняття стресів; 73,8\% - фізичні вправи для профілактики викривлення хребта; 69,0\% - опанування засобами фізичного самовдосконалення. $52,4 \%$ бажають сформувати вміння щодо використання реабілітаційних вправ при різних захворюваннях. Однак $є$ й такі студенти $(47,6 \%)$, котрі хочуть сформувати практичні вміння щодо використання природних засобів загартування. Отримані відповіді репрезентовано на рис. 3 .

Окрім інтересу до зазначених вище прийомів регулятивно-оздоровчої дії, майбутні лікарі виявили зацікавленість до формування вмінь щодо використання прийомів контролю за власним здоров'ям $(83,01 \%)$ та методики прогнозування здоров'я, тривалості життя (58,09\%).

Таким чином, схвальними є високе зацікавлення і готовність майбутніх лікарів удосконалюватися та формувати практичні валеологічні компетенції, що сприятиме підви- 


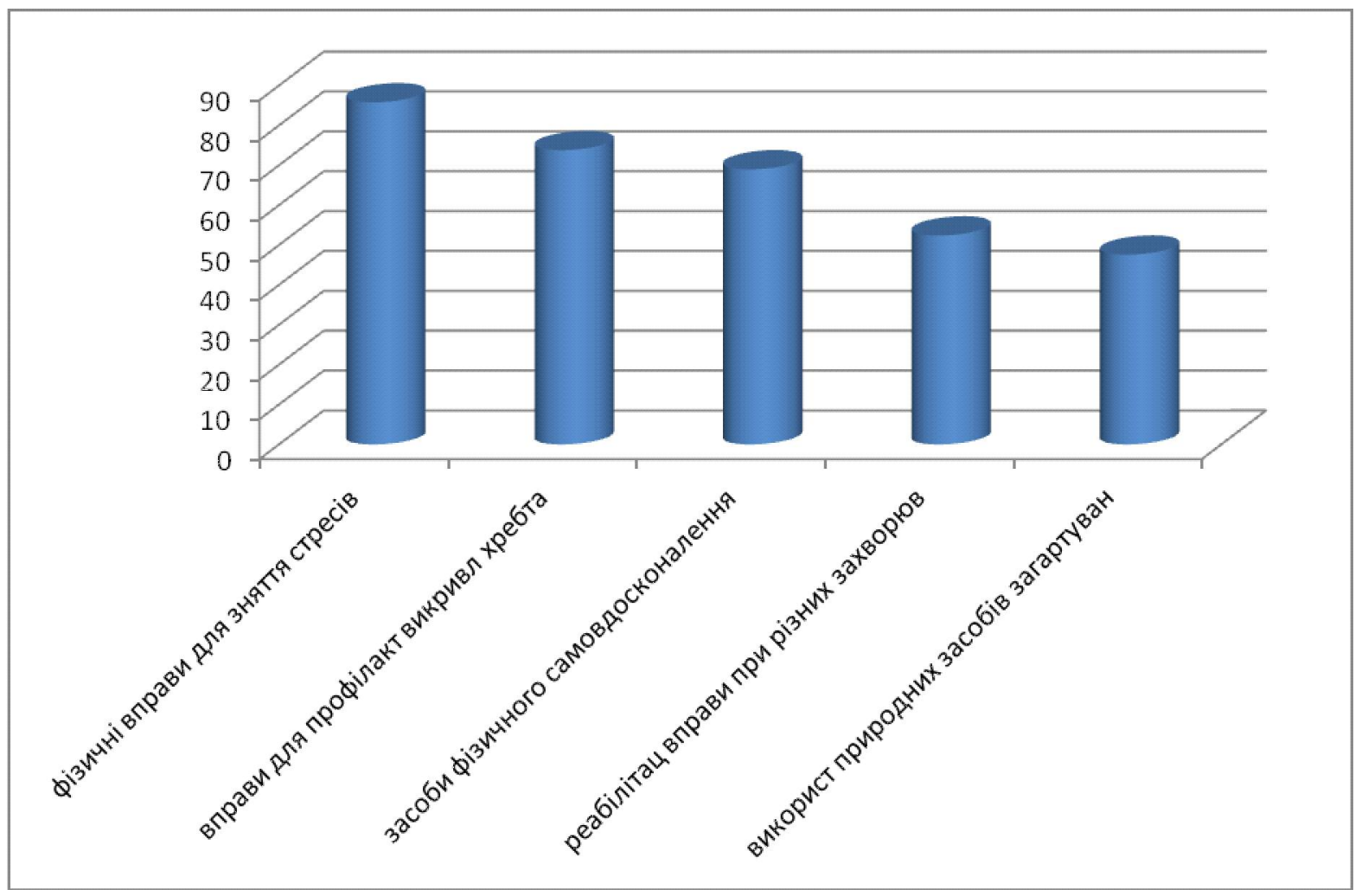

Рис. 3. Рейтинг використання засобів для підвищення формування

практичних валеологічних компетенцій майбутніх лікарів

щенню рівня здоров'я, корекції власного способу життя та життевих цінностей майбутніх пацієнтів.

Ще одне питання 3 практичної частини анкети мало на меті встановити, з яких інформаційних джерел студенти-медики поповнюють валеологічні знання. Їхні відповіді розприділилися порівну (по 88,1\%), тобто пріоритетними виявилися як самоосвіта, так і засоби масової інформації; $81,0 \%$ респондентів вказали на заняття у навчальному закладі; $61,9 \%-$ участь у науково-практичних конференціях.

Опрацювання відповідей студентів щодо обрання п'яти методів, які на їхню думку доцільно використовувати для пропаганди валеологічної освіти, показало, що на перше місце 90,4\% респондентів винесли лекції, відтак-тренінги (83,3\%); 78,5\% осіб вважають, що саме індивідуальні бесіди 3 пацієнтами стануть ефективним засобом для формування валеологічної обізнаності. Немаловажними будуть також і науково-практичні конференції, на на чому наголошують $61,9 \%$ опитаних; 47,6\% респондентів назвали круглі столи.

Висновки та перспективи по- дальших досліджень. Отже, проведене опитування студентів-інтернів щодо моніторингу стану валеологічної компетентності виявило, що більшість 3 них переймається не тільки власним здоров'ям, а і здоров'ям суспільства загалом. На це вказує їх готовність щодо розширення теоретичних валеологічних знань та підвищення рівня сформованості практичних валеологічних умінь. Майбутні лікарі позиціонують бажання застосовувати традиційні та сучасні засоби пропаганди валеологічної освіти.

Подальші дослідження з означеної проблематики будуть спрямовані на розроблення технології формування валеологічної компетентності майбутніх лікарів та рекомендацій щодо підвищення їх рівня валеологічної освіченості.

\section{СПИСОК ЛІТЕРАТУРИ}

Алексеенко, С. Н., Авдеева, М. Г. $\&$ Дробот, Е. В. (2013). Ценностномотивационные приоритеты студентов медицинского вуза в отношении здорового образа жизни. Фундаментальные исследования, 2-1, 16-19
Бондаренко, О. М. (2008). Формування валеологічної компетентності студентів педагогічних університетів у процесі професійної підготовки. (Автореф. дис. ...канд. пед. наук), Київ.

Власов, Г. В. (2012). Формування здорового способу життя студентів вищих медичних навчальних закладів засобами фізичного виховання. (Автореф. дис... канд. пед. наук), Луганськ.

Єлізаров, В. П. (2016). Формування валеологічної компетентності студентів у позааудиторній виховній роботі університету. (Автореф. дис. ...канд. пед. наук), Харків.

Козуб, С. М. \& Чаленко, Н. М. (2016). Формування культури здоров'я студентів вищих медичних навчальних закладів. Актуальні питання соціальної медицини, організації та економіки охорони здоров'я в Україні, Матеріали наук.-практ. конф., Харків: ХНМУ.

Кульбашна, Я. А. \& Ткачук, О. Г. (2016). Формування загальних компетентностей майбутніх лікарів. Педагогічний процес: Теорія і практика, 4(55).

Назарук, В. Л. (2014). Педагогічні 
умови формування культури здоров'я майбутніх лікарів. Науковий вісник Ужгородського національного університету, 34, 124-126.

Новакова, Л. В. (2013). Формування культури здоров'я майбутніх лікарів як педагогічна проблема. Вісник Національного університету оборони Украӥни, 5 (36), 68-72.

Остафійчук, Я. Ф. (2014). Формування валеологічних компетенцій у студентів медичних коледжів у процесі фізичного виховання. (Дис... канд. фіз. вих.), Івано-Франківськ.

Radziminska, A., Weber-Rajek, M., Lulinska-Kuklik, E., Kazmierczak, U. Moska, W. (2016). Academic youth's health behavior. Физическое воспитание студентов, 6, 55-62.

Сапожник, О. (2010). Аналіз стану збереження здоров'я студентської молоді. Фізичне виховання, спорт $i$ культура здоров'я у сучасному суспільстві, 4(12), 52-55.

Шостак, I. (2017). Формування культури здоров'я студентів медичних коледжів у позааудиторній діяльності. (Дис... канд.. пед. наук: 13.00.07). Кіровоградський державний педагогічний університет імені Володимира Винниченка. Кропивницький.

\section{REFERENCES}

Alekseenko, S. N., Avdeeva M. G. \& Drobot Ye. V. (2013). Tsennostno- motivatsionnye prioritety studentov meditsinskogo vuza $\mathrm{v}$ otnoshenii zdorovogo obraza zhizni. Fundamentalnye issledovaniya, 2-1, 16-19.

Bondarenko, O. M. (2008). Formation of valeological competence of students of pedagogical universities in the process of professional training : Teoriia i metodyka profesiino osvity.

Vlasov, H. V. (2012). Formation of a healthy way of life of students of higher medical educational institutions by means of physical education. Teoriia $i$ metodyka profesiinoi osvity.

Yelizarov, V. P. (2016). Formuvannia valeolohichnoi kompetentnosti studentiv u pozaaudytornii vykhovnii roboti universytetu. Teoriia $i$ metodyka profesiinoi osvity.

Kozub, S. M. \& Chalenko N. M. (2016). Formuvannia kultury zdorov'ia studentiv vyshchykh medychnykh navchalnykh zakladiv. Aktualni pytannia sotsialnoi medytsyny, orhanizatsii ta ekonomiky okhorony zdorov'ia v Ukraini, Materialy nauk.prakt. konf.

Kulbashna, Ya. A. \& Tkachuk O. H. (2016). Formuvannia zahalnykh kompetentnostei maibutnikh likariv. Teoriia i praktyka, 4 (55).

Nazaruk, V. L. (2014). Pedahohichni umovy formuvannia kultury zdorov'ia maibutnikh likariv. Naukovyi visnyk Uzhhorodskoho natsionalnoho universytetu, 124-126.

Novakova, L. V. (2013). Formuvannia kultury zdorov'ia maibutnikh likariv yak pedahohichna problema. Visnyk Natsionalnoho universytetu oborony Ukrainy, 5 (36), 68-72.

Ostafiichuk, Ya. F. (2014). Formuvannia valeolohichnykh kompetentsii u studentiv medychnykh koledzhiv u protsesi fizychnoho vykhovannia. (Dys. ...kand. fiz. vykh). Prykarpatskyi natsionalnyi universytet imeni Vasylia Stefanyka, IvanoFrankivsk.

Radziminska, A., Weber-Rajek, M., Lulinska-Kuklik, E., Kazmierczak, U. \& Moska, W. (2016). Academic youth's health behavior. Fyzycheskoe vospytanye studentov, 6, 55-62.

Sapozhnyk, O. (2010). Analiz stanu zberezhennia zdorovia studentskoi molodi. Fizychne vykhovannia, sport i kultura zdorov'ia u suchasnomu suspilstvi, 4 (12), 52-55.

Shostak, I. (2017). Formuvannia kultury zdorov'ia studentiv medychnykh koledzhiv u pozaaudytornii diialnosti. (Dys. ...kand. ped. nauk). Kirovohradskyi derzhavnyi pedahohichnyi universytet imeni Volodymyra Vynnychenka, Kropyvnytskyi.

Стаття надійшла 30.10.2019 р. 